УДК 343.148

DOI https://doi.org/10.51989/NUL.2021.4.41

\title{
СУЧАСНІ МОЖЛИВОСТІ СУДОВИХ ЕКСПЕРТИЗ I НАПРЯМИ ВИКОРИСТАННЯ СПЕЦІАЛЬНИХ ЗНАНЬ У РОЗСЛІДУВАННІ ЗЛОЧИНІВ, ПОВ'ЯЗАНИХ ІЗ ЛІСОМ
}

\author{
Троханенко Олександр Михайлович, \\ заступник завідувача відділу - завідувач сектору товарознавчих \\ та гемологічних досліджень \\ Рівненського науково-дослідного експертно-криміналістичного центру \\ Міністерства внутрішніх справ України
}

\section{Комісарова Анжела Дмитрівна,}

старший судовий експерт сектору товарознавчих та гемологічних досліджень Рівненського науково-дослідного експертно-криміналістичного центру Міністерства внутрішніх справ України

\section{Верба Віктор Вікторович,}

старший судовий експерт сектору трасологічного обліку

Рівненського науково-дослідного експертно-криміналістичного центру

Міністерства внутрішніх справ України

У статті продемонстровано сучасні можливості судової трасологічної, економічної і товарознавчої експертиз під час проведення початкового етапу розслідування незаконної порубки лісу.

Розкрито поняття оцінки лісоматеріалів та визначено підходи, що застосовуються під час проведення судової товарознавчої експертизи. Особливу увагу приділено принципам нової класифікації в лісової галузі, де встановлено класи якості сортиментів за фактом на основі оновлених чинних нормативних документів, які базуються на європейській системі стандартизації. Зазначено основні принципи класифікації, відповідно до яких визначається клас якості лісоматеріалів круглих. Схематично наведено основні терміни, які використовуються в лісовій галузі. Встановлено, що кожен з указаних підходів реалізується за допомогою специфічних методик, які безпосередньо залежать від об'єкта оцінки. Викладені основні поняття і терміни, що використовуються під час проведення дослідження круглих лісоматеріалів. Виділено два етапи дослідження споживчих властивостей дерев, зокрема оцінювання якості та оцінювання вартості. Зазначено про особливі випадки проведення комплексних товарознавчо-біологічних досліджень чи досліджень із залученням фахівців у галузі лісництва. Перелічено вихідні дані, за наявності яких експерт-товарознавець може приступити до визначення ринкової вартості круглих лісоматеріалів. Обґрунтовано доцільність застосування витратного та порівняльного підходів під час проведення експертизи. У статті наведено рекомендований алгоритм типового дослідження даного виду об'єктів, відповідно до якого визначається товарна приналежність об'єктів, розмір

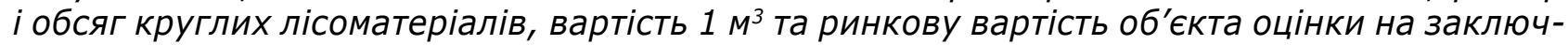
ному етапі. Автори розкривають предмет, об'єкт, виділяють основні типові питання, які можуть бути поставлені перед експертами, а також завдання, які вирішуються в рамках ії проведення. Визначено межі компетенції експертів. Матеріали та напрацювання статті можуть бути використані фахівцями науково-дослідних експертно-криміналістичних центрів МВС України для врахування в роботі під час проведення трасологічної, економічної та товарознавчої експертиз, що забезпечить систематизацію та методичну одноманітність експертної практики, розширить можливості таких експертиз.

Ключові слова: лісоматеріали, ділова деревина, класи якості, розмір шкоди, ринкова вартість, судова товарознавча експертиза, трасологічна експертиза, колода, дошка. 


\section{Trokhanenko Oleksandr, Komisarova Anzhela, Verba Viktor. Modern possibilities of forensic examinations and directions of using special knowledge in the investigation of forest-related crimes}

The article demonstrates the modern possibilities of logical, economic and commodity expertise during the initial stage of the investigation of illegal logging.

The article reveals the concept of timber assessment and identifies the approaches used during the forensic examination. Particular attention is paid to the principles of the new classification in the forest industry, which sets the quality classes of assortments in fact, guided by updated current regulations based on the European standardization system. The basic principles of classification according to which the class of quality of round timber is defined are specified. The basic terms used in the forest industry are schematically given. It is established that each of these approaches is implemented using specific techniques that directly depend on the object of evaluation. The basic concepts and terms used in the study of round timber are described. There are two stages of research of consumer properties of trees, in particular quality assessment and cost assessment. Special cases of conducting complex commodity-biological research or research involving specialists in the field of forestry are mentioned. The initial data are listed, in the presence of which the expert commodity expert can begin to determine the market value of round timber. The expediency of using cost and comparative approaches during the examination is substantiated. The article presents the recommended algorithm of a typical study of this type of objects, according to which the commodity affiliation of objects, size and volume of round timber, the cost of $1 \mathrm{~m}^{3}$ and at the final stage, the market value of the object of assessment is determined. The author reveals the subject, object, identifies the main typical questions that can be posed to the expert-commodity expert, as well as the tasks that are solved in the framework of its implementation. Defines the limits of competence of the expert-commodity expert. Materials and developments of the article can be used by specialists of research forensic centers of the Ministry of Internal Affairs of Ukraine to take into account in the work during commodity examinations, which will provide systematization and methodological uniformity of expert practice, expand the possibilities of such assessment.

Key words: timber, business timber, quality classes, market value, the amount of damage, forensic examination, trasological examination, deck, board.

Важливою складовою частиною навколишнього природного середовища $\epsilon$ ліс. Ліси України - це ії національне багатство, яке за своїм призначенням виконує переважно водоохоронні, захисні, санітарно-гігієнічні, оздоровчі, рекреаційні, естетичні, виховні, інші функції та $€$ джерелом для задоволення потреб суспільства в лісових ресурсах.

Деревина - основна продукція лісів. Деревину споживають усі галузі народного господарства. Раціональне використання деревини й інших лісових багатств - важлива частина природоохоронної діяльності, яка відображена в Лісовому кодексі України (далі - ЛКУ).

Лісове господарство України $€$ принципово вагомим з екологічної точки зору національним ресурсом. Проведений аналіз статистичних даних і численних публікацій у засобах масової інформації свідчить, що, на превеликий жаль, вітчизняні лісові ресурси давно перетворилися на об'єкт систематичних кримінальних посягань «чорних лісорубів», що завдають масштабних збитків легальній лісовій промисловості.

Приклади використання судових експертиз залежно від різновиду кримінального правопорушення у сфері лісового господарства було розглянуто в працях закордонних і вітчизняних учених, зокрема І.С. Зинов'євої, О.С. Кленнікової, О.П. Кудревич, І.А. Фоміної, А.І. Вінберга, В.Г. Гончаренка, О.М. Пилипенко, Н.П. Майліс, В.К. Стрінжі та ін.

Дисертаційні дослідження з питань розслідування злочинів, пов'язаних з незаконним вирубуванням лісових насаджень та обігом лісу і лісопродукції, проводилися М.А. Васильєвою (2014), А.В. Корольовим (2009), С.В. Унжаковою (2013), I.А. Фоміною (2011).

Роботи зазначених вище вчених внесли істотний внесок у формування теорії і практики кримінально-правової охорони лісів. Однак розвиток законодавства і суспільних відносин у сфері використання лісів вимагає актуалізації та вдосконалення накопичених наукових знань. 
Крім того, більшість існуючих досліджень присвячені розгляду лише незаконної рубки лісових насаджень та (або) знищення або пошкодження лісових насаджень і не містять окремого ґрунтовного наукового дослідження особливостей проведення початкового етапу досудового розслідування незаконної порубки лісу, яке би враховувало вимоги вітчизняного законодавства та регіональну специфіку українських лісів, що зумовлює актуальність його проведення. Для повноцінного дослідження вилучених речових доказів, для повного та швидкого розслідування й запобігання таким злочинам з'являється потреба в сучасних рекомендаціях щодо призначення доцільних судових експертиз на початковому етапі розслідування незаконної порубки лісу та визначення розміру завданих збитків.

Метою статті $\epsilon$ висвітлення сучасних можливостей судової експертизи, проведення якої $\epsilon$ необхідним на початковому етапі досудового розслідування незаконної порубки лісу.

Під час розслідування даних злочинів для з'ясування обставин, що мають значення для кримінального провадження, виникає необхідність у наукових, технічних або інших спеціальних знаннях, які необхідні для вирішення завдань у кримінальному провадженні, тому за зверненням сторони кримінального провадження або за дорученням судді чи суду призначається судова експертиза. Аналізуючи слідчу практику у сфері незаконної порубки лісу, можна виділити три основні види судових експертиз, які найчастіше призначаються: трасологічну (експертиза цілого за частинами), товарознавчу та економічну.

Усі ліси на території України, незалежно від того, на землях яких категорій за основним цільовим призначенням вони зростають, та від права власності на них, становлять лісовий фонд України й перебувають під охороною держави.

Одним із найбільш розповсюджених кримінальних правопорушень, які становлять питому вагу цих екологічних злочинів, $\epsilon$ незаконна порубка лісу (ст. 246 Кримінального Кодексу України).

Нерідко об'єктами трасологічних досліджень $€$ частини деревини, в тому числі з метою встановлення цілого за частинами. Встановити факт, що фрагменти зрізів пнів і зрізів нижніх частин стовбурів дерев складали одне ціле, дає можливість саме судова експертиза цілого за частинами.

У зв'язку з цим для притягнення злочинців до відповідальності виникає необхідність «прив'язки» деревини до місця злочину, тобто до залишків дерев (пеньків). Зазвичай типове дослідження по зрізах деревини, виконаних у поперечних площинах, не викликає особливих труднощів. Послідовність дій та методів дослідження викладено в методиці встановлення цілого за частинами (експертна спеціальність 4.2 «Дослідження знарядь, агрегатів, інструментів і залишених ними слідів, ідентифікація цілого за частинами») [1], а характерні ознаки та особливості наведено в методичних рекомендаціях «Дослідження частин деревини та слідів її розділення» [2].

В умовах сьогодення незаконно здобуту деревину злочинці якомога швидше відправляють на розпилювання з метою знищення будь-яких слідів взаємозв'язку з первинною сировиною. Адже вигляд видозмінених колод, розрізаних на деревообробному станку, може викликати як у працівників правоохоронних органів, так і в спеціалістів, розгубленість і невизначеність щодо подальших дій.

Першопочатковим завданням, що ставиться перед експертом-трасологом, $\epsilon$ вирішення питання: «Чи складали між собою досліджувані дошки одну колоду до розділення?».

Основні етапи для огляду, підготовки та дослідження пиломатеріалів (дошок) і встановлення їх цілого за частинами такі:

I етап. Розділення (сортування) досліджуваної деревини на породи (у разі надання різних порід) та встановлення розмірних характеристик об'єктів.

II етап. Виявлення ознак, що характеризують:

- зовнішню та внутрішню будову:

- колір окремих ділянок і шарів деревини;

- конфігурацію та розташування річних шарів;

- особливості кори (за наявності);

- наявність і розташування сучкових включень; 
- вади деревини:

- наявність та локалізацію тріщин;

- наявність, забарвлення та конфігурацію ділянок гнилі;

- пошкодження та їх походження.

III етап. Конструювання першопочаткової форми колоди (або ії частини).

IV етап. Результати проведених досліджень та експериментів аналізуються, оцінюються та узагальнюються. На основі встановлених збіжних чи розбіжних ознак формуються обґрунтовані висновки.

Підсумовуючи результати проведених емпіричних та практичних досліджень, а також ураховуючи отримані кінцеві позитивні результати, можна стверджувати, що дослідження даного виду об'єктів деревини $\epsilon$ попереднім етапом для подальшого ідентифікаційного дослідження цілого за частинами відновлених колод (стовбурів) з площинами пнів і верхівок зрізаних дерев.

Зазвичай злочини, пов'язані з обігом нелегальної лісопродукції, кваліфікуються лише як незаконна порубка, хоча порушників часто затримують не в момент безпосередньої заготівлі деревини, а під час іï транспортування або зберігання.

Завдання правоохоронних органів у цих ситуаціях - встановити походження вже зрубаної деревини та водночас довести вину причетних до цього осіб. У таких справах призначаються економічна експертиза для вирішення питань про підтвердження розміру шкоди, заподіяної лісу в результаті незаконної порубки дерев.

Судова економічна експертиза вирішує запитання щодо документального та нормативного підтвердження розрахунків розміру шкоди, заподіяної внаслідок незаконної вирубки або пошкодження дерев у лісі та в межах населених пунктів, які складені державними інспекторами з охорони навколишнього природного середовища. Експертами-економістами Рівненського НДЕКЦ виконано 25 судових експертиз, якими підтверджено розмір шкоди, заподіяної лісу незаконною рубкою дерев, на загальну суму понад 1,3 млн грн [3].

За останні роки спостерігається невтішна тенденція зростання обсягів незаконних вирубок. Обсяги незаконної рубки лісу та суми завданих збитків, які визначені в Рівненському НДЕКЦ МВС про- тягом першого півріччя 2020 року, наведено на рис. 1.

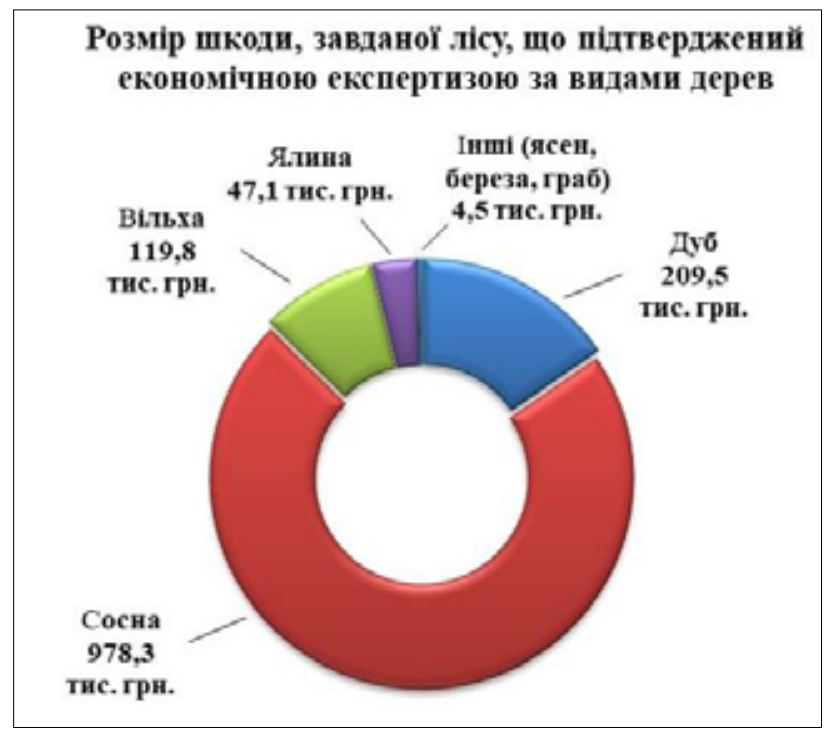

\section{Рис. 1. Обсяги незаконної рубки лісу та суми завданих збитків (за даними Рівненського НДЕКЦ МВС)}

Під час розслідування й судового розгляду різних категорій кримінальних і цивільних справ часто виникає також необхідність у вирішенні запитань, пов'язаних із визначенням ринкової вартості лісоматеріалів, і саме товарознавча експертиза надає можливість отримати висновок судового експерта щодо даного питання.

Лісоматеріали отримують шляхом механічної обробки дерев, що повалили, і їхніх частин. Стовбур поваленого дерева, очищений від гілок, верхівки і пневої частини, називають деревним хлистом. Заготовляють ділову деревину і паливну деревину (дрова), яка придатна для використання тільки у вигляді палива. Ділова деревина група лісових матеріалів, що виробляються з деревини для потреб виробництва і населення в круглому вигляді (лісоматеріали круглі). Низькоякісну ділову деревину називають технологічною сировиною.

З 2019 року Україна перейшла на нові національні стандарти якості деревини, гармонізовані 3 європейськими. У них суттєво змінені підходи до визначення розмірноякісних характеристик лісо та пиломатеріалів. Якщо раніше ділова деревина (лісоматеріали круглі) в Україні розподілялася на три сорти (I, II, III) 
та мала низку сортиментів за їх призначенням, то з 2019 року розподіляється на чотири класи якості (A, B, C, D), як і в європейських країнах.

Принцип класифікації за європейською системою стандартизації лісоматеріалів круглих не базується на призначенні сортиментів, а в основі його - показники розміру та якості колод; більший діаметр і мінімальний вміст вад деревини за встановленого приросту - вищий клас якості:

- до класу якості А прийнято відносити лісоматеріали найвищого класу якості, які в більшості походять із нижньої частини колоди, з чистою деревиною або з незначними вадами, які не обмежують її використання;

- до класу якості В прийнято відносити лісоматеріали середнього класу якості, без особливих вимог до чистої деревини та сучками в межах середнього значення для кожної породи;

- до класу якості С прийнято відносити лісоматеріали нижче середнього класу якості, в яких дозволяються ті вади, які незначно знижують природні властивості деревини як матеріалу;
- до класу якості D має бути віднесено лісоматеріали, що не задовольняють жодному із класів якості A, B, C, але з яких ще може бути отримано пиломатеріали для подальшого використання [4].

Всі інші лісоматеріали круглі, з яких неможливе отримання пиломатеріалів для загального використання, класифікуються як:

а) деревина дров'яна для промислового використання, довжиною 2,0-4,0 метри (виробництво трісок технологічних чи паливного призначення, розколювання на паливну деревину тощо);

б) деревина дров'яна для непромислового використання, довжиною до 2-х метрів (може бути реалізована фізичним і юридичним особам як паливо) (рис. 2).

Ринкова вартість круглих лісоматеріалів визначається з урахуванням конкретної експертної ситуації і завдань, поставлених на вирішення експертам.

Дослідження доречно проводити за алгоритмом, відповідно до якого необхідно визначити:

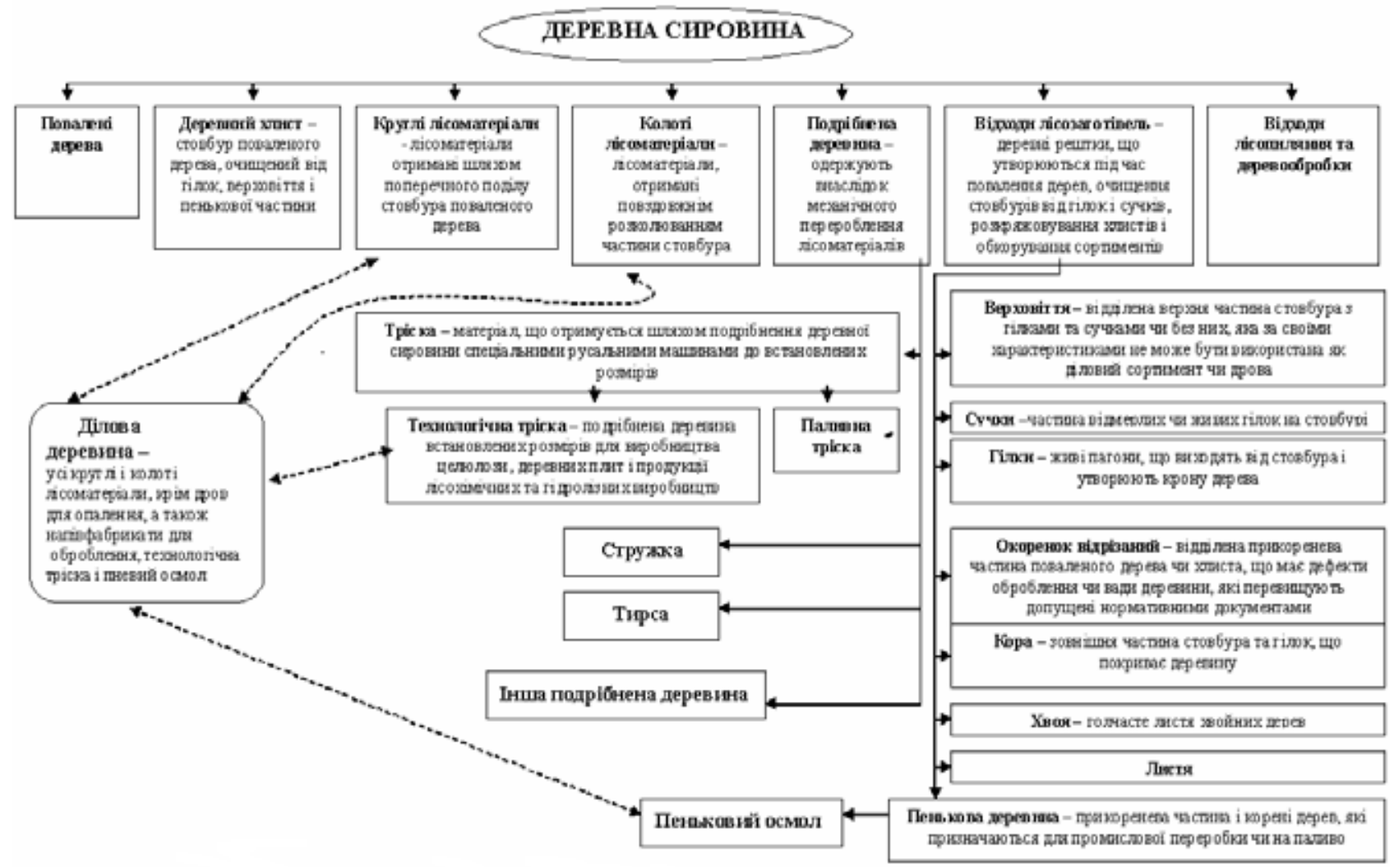

Рис. 2. Терміни, що стосуються лісоматеріалів 
1. Товарну приналежність об'єктів.

2. Розмір і обсяг (кількість) круглих лісоматеріалів:

- довжина і товщина круглих лісоматеріалів - вимірювальним методом із застосуванням металевої рулетки і штангенциркуля з ціною поділки 1 мм (згідно з ТУУ-00994207-004:2018).

- обсяг круглих лісоматеріалів розрахунковим методом (відповідно до ДСТУ EN 1310-2005).

3. Вартість $1 \mathrm{~m}^{3}$ круглих лісоматеріалів на момент скоєння злочину на підставі розрахунку вартості лісопродукції, наданої державними підприємствами лісового господарства, або інформації з мережі Інтернет про ціни продажу (пропонування) подібного майна.

4. Ринкову вартість об'єкта оцінки (круглих лісоматеріалів) в цінах на момент скоєння злочину за допомогою розрахункового методу.

Відповідно до Національного стандарту № 1 (ПКМУ №1440 від 10.09.2003р.) існують такі методичні підходи визначення вартості: витратний, дохідний, порівняльний [6].

Витратний підхід передбачає визначення поточної вартості витрат на відтворення або заміщення об'єкта оцінки з подальшим коригуванням їх на суму зносу (знецінення). Дохідний підхід базується на врахуванні принципів найбільш ефективного використання та очікування, відповідно до яких вартість об'єкта оцінки визначається як поточна вартість очікуваних доходів від найбільш ефективного використання об'єкта оцінки, включаючи дохід від його можливого перепродажу. Порівняльний підхід ґрунтується на врахуванні принципів заміщення та попиту і пропозиції. Порівняльний підхід передбачає аналіз цін продажу і пропозицію подібного майна з відповідним коригуванням відмінностей між об'єктами порівняння та об'єктом оцінки.

Для визначення ринкової вартості даного виду об'єктів дослідження доцільно використовувати порівняльний методичний підхід.

Порівняльний підхід з визначення ринкової вартості використовується в разі розвиненого ринку на певні види лісоматеріалів, які досліджуються в судовій товарознавчій експертизі. Змістом порівняльного підходу $\epsilon$ порівняння характеристик досліджуваних об'єктів з характеристиками інших об'єктів, виставлених на продаж або проданих на ринку, ціни на які відомі на визначену слідством дату.

Отже, особливістю проведення судової товарознавчої експертизи з визначення вартості лісоматеріалів $\epsilon$ те, що експерт повинен чітко дотримуватись алгоритму дослідження даних об'єктів, орієнтуватися в змінах, що викладаються в різних нормативних документах, які стосуються лісоматеріалів.

Слід завжди пам'ятати, що успішне розслідування незаконної рубки лісових насаджень у значній мірі залежить від правильного, своєчасного, всебічного і якісного використання спеціальних знань. Основною формою використання спеціальних знань під час розслідування даних злочинів $€$ призначення судових експертиз, зокрема трасологічної, економічної, товарознавчої та інших.

\section{ЛИТЕРАТУРА:}

1. Методика встановлення цілого за частинами експертна спеціальність 4.2 «Дослідження знарядь, агрегатів, інструментів і залишених ними слідів, ідентифікація цілого за частинами». Київ : ДНДЕКЦ МВС України, 2015. Реєстраційний код 4.2.35.

2. Бухонський С.О. Дослідження частин деревини та слідів їі розділення : методичні рекомендації. Київ : ДНДЕКЦ МВС України, 2016. 29 с.

3. Судова експертиза, як невід'ємна частина боротьби з незаконною порубкою лісу. URL: https://ndekc-rv.gov.ua/novini-ndekc/novyny/437-sudova-ekspertyza-iak-nevidiemnachastyna-borotby-z-nezakonnoiu-porubkoiu-lisu

4. Україна перейшла на нові національні стандарти якості деревини, гармонізовані з європейськими. URL: http://dklg.kmu.gov.ua/forest/control/uk/publish/article?art_id=197884

5. Закон України «Про оцінку майна, майнових прав та професійну оціночну діяльність в Україні» від 12.07.2001 р. № 2658-III.

6. Національний стандарт №1 «Загальні засади оцінки майна і майнових прав» від 10.09.2003 р. № 1440. 
7. Грановский Г.Л. Основы трасологии. Особенная часть. Москва : ВНИИ МВД СССР, 1974. 240 с.

8. Розанов М.И. Возможности установления целого по частям при исследовании древесины и изделий из нее. Криминалистика и судебная экспертиза. Киев : Киевский НИИСЭ, 1964. Вып. 1. С. 208-215.

9. ДСТУ 4020-2-2001. Лісоматеріали круглі та пиляні. Методи обмірювання та визначення об'ємів. Частина 2. Лісоматеріали круглі (pr EN 1309-2:1998).

10. ДСТУ EN 1310:2005. Лісоматеріали круглі та пиляні. Метод вимірювання параметрів (EN 1310:1997, IDT).

11. СТУ EN 518:2003. Лісоматеріали конструкційні. Сортування. Вимоги до стандартів на візуальне сортування за міцністю (EN 518:1995, IDT).

12. ДСТУ EN 1315-1-2001. Класифікація за розмірами. Частина 1. Лісоматеріали круглі листяні (EN 1315-1:1997, IDT).

13. ДСТУ EN 1315-2-2001. Класифікація за розмірами. Частина 2. Круглі лісоматеріали хвойних порід (EN 1315-2:1997, IDT).

14. ДСТУ EN 1313-2:2018. Лісоматеріали круглі та пиляні. Допустимі відхили та переважні розміри. Частина 2. Пиломатеріали твердолистяних порід (EN 1313-2:1998, IDT). 